\section{Regime building in the Malacea and Singapore straits: two steps forward, one step back}

\section{Sam Bateman}

$\mathrm{W}$

ith the economic growth of Asia, the Malacca and Singapore straits now constitute the most economically important waterway in the world. The main shipping channels between the Indian and Pacific oceans, they carry nearly half of the world's annual seaborne trade, including oil supplies. According to data compiled by the Ministry of Land, Transport, and Infrastructure in Japan, nearly 94,000 vessels used the straits in 2004 , a figure thought to rise to 150,000 vessels by 2020 , with tankers in the energy trade accounting for much of the increase. ${ }^{1}$ Consequently, the construction of an effective regime of maritime safety, security, and environmental protection in the Malacca and Singapore straits has received much attention in recent years. Many countries have a stake in shipping passing through the straits, and their interests are diverse and divergent. User states have been concerned about the high level of piracy and seaborne armed robbery in the straits and, following the 11 September 2001 (9/11) terror event in the United States, the possibility that a maritime terror attack could disrupt shipping in the straits. ${ }^{2}$ Littoral states countries bordering the straits — are worried about the implications of increased shipping traffic, the threats posed to the marine environment, the high costs of maintaining navigational safety and environmental protection, and the possibility that their sovereignty could be jeopardized by the operational involvement of nonlittoral countries in providing security in the straits.

Regarding piracy and armed robbery, the International Maritime Bureau (IMB) reports a significantly improved record over the past five years or so: for example, 38 attacks were reported in the Malacca strait in 2003; this number has fallen with only two attacks reported in 2008. ${ }^{3}$ A downward trend is less evident in the Singapore strait with an average of about five attacks reported each year. This reflects shipping concentrations in the Singapore strait, including many slow-moving, small vessels and ships at anchor, and the presence of opportunistic pirates in the Riau archipelago.

Building an effective regime for maritime safety, security, and environmental protection in the straits has proven difficult due mainly to the diverse nature of the interests involved. Brokering agreement between these interests has required the involvement of the International Maritime Organization (IMO), which is the relevant transnational institution concerned with global shipping safety and security and the prevention of pollution by ships. Greater cooperation among littoral states in regional structures to ensure safety and security has also been evident. Managing maritime safety and security in the straits is a major challenge that is high on the agenda of regional summits and conferences.

\section{Stakeholder perspectives}

Perspectives on priorities for action in regime building vary both between and within user and littoral countries. The terror attack of $9 / 11$ and subsequent measures to reduce terrorism risks have triggered much of the recent attention given to the straits, but even with these new measures, perspectives on the relevant priorities for action have varied. In particular, user states attach priority to implementing these measures, but Indonesia and Malaysia believe the risk of maritime terrorist attack in the straits is low. Moreover, they suggest that it would be difficult, if not impossible, to physically block the straits and reject the more extreme scenarios for a terrorist attack. They also suspect some of the major nonlittoral countries are talking up risks only to justify a strategic presence in the straits. ${ }^{4}$

\section{Littoral countries}

Indonesia and Malaysia are concerned about sovereignty and sovereign rights in the straits and believe that they carry an unfair burden in ensuring the safety and security of shipping and protecting the marine environment. Coastal states adjoining an international strait do have considerable service responsibilities for vessels transiting the strait, for example, for the provision and maintenance of navigational aids, communications systems, hydrographic charts and other navigational information, search and rescue services, offshore security services, basic vessel salvage services, and marine pollution contingency arrangements. While the littoral countries accept that piracy and the threat of maritime terrorism are problems, they are equally worried about other issues of law and order at sea, such as the trafficking of arms, drugs, or people, illegal fishing, and pollution of the marine environment. Both Malaysia and Indonesia have extensive fishing interests in the waters of the Malacca strait and, additionally, Malaysia has major tourist developments on its west coast that depend heavily on a clean marine environment.

The littoral states argue that most of the shipping passing through the straits does not call at any port in the straits. But the straits are also used by extensive coastal and domestic shipping which share the use of services with international shipping transiting through the straits. Due to the lack of land-based transport infrastructure in most parts of Southeast Asia, including the Indonesian island of Sumatra, large numbers of smaller merchant vessels, particularly product tankers and general cargo ships, also ply their trades in the straits, as well as smaller container ships on feeder 
services from the main container ports of Singapore, Port Klang, and Tanjung Pelepas. User states and international shipowners thus believe the local need for navigational aids and security should be acknowledged when apportioning the costs of providing services in the straits.

Initiatives in the straits by littoral countries are overseen by tripartite ministerial meetings among Indonesia, Malaysia, and Singapore. The first meeting of this group since 1971 was held in Batam in August 2005. Technical matters relating to the management of the straits over the years have been handled by regular meetings of the Tripartite Technical Experts Group (TTEG). The Batam meeting resulted in the Batam Joint Statement, which inter alia, welcomed closer collaboration with and the assistance of user states and relevant international organizations, and supported continuing discussion on maritime security in the Southeast Asian region within the framework of ASEAN and the ASEAN Regional Forum (ARF). ${ }^{5}$ It agreed that maritime security should be addressed comprehensively and include such issues as piracy, seaborne robbery, terrorism, smuggling or trafficking people or weapons, and other transboundary crimes.

The littoral countries do not always speak with one voice. Singapore tends to side with major nonlittoral maritime powers in seeking maximum freedom of navigation. It thus usually opposes initiatives to place additional restrictions on ships using the straits. It has also been much more prepared than its neighbors to accept operational assistance from nonlittoral countries in maintaining security in the straits. Sometimes it appears that Indonesia and Malaysia are reluctant even to concede that Singapore is a littoral country to the Malacca strait. ${ }^{6}$

\section{Northeast Asian countries}

China, Japan, Taiwan, and South Korea are heavily dependent on shipping through the Straits. This includes tankers and gas carriers moving from the Middle East, and large container ships on around-the-world service runs among Europe, East Asia, and North America as well as other types of vessel, such as car carriers and roll-on, rolloff ("ro-ro") vessels carrying important export and import commodities."

Of these states, Japan has been the most active in assisting the littoral countries with their efforts to provide safety and security in the straits and to protect the marine environment. For many years, it has been the only user state contributing to the costs of safety and environmental protection in the straits. More recently, it initiated several regional measures to combat piracy and maritime terrorism, notably the Regional Cooperation Agreement on Combating Piracy and Armed Robbery against Ships (ReCAAP), discussed later on in the article. Japan Coast Guard ships and aircraft regularly visit Southeast Asian states to assist local security forces through training and exercises in building their capacity to combat threats from piracy and maritime terrorism. In June 2006, Japan donated three patrol boats to Indonesia to help fight terrorism and piracy, after earlier donating a training vessel to the Malaysian Maritime
Enforcement Agency. In January 2008, Japan announced a grant of nearly US\$4 million to assist in upgrading Malaysia's maritime surveillance system along the Malacca strait. ${ }^{8}$

Japan's concerns for navigational safety and security in the straits are now shared by China, which is seeking a more active role in contributing to safety and security in the straits. This is a consequence of China's "Malacca dilemma," i.e., China's increased dependence on oil shipments though the straits, and the possibility that the United States might target these in the event of conflict over Taiwan or in some other circumstances. ${ }^{9}$ China is increasingly wary of other powers assuming a preeminent role in maintaining security in the straits.

Japan has its own Malacca dilemma. For many years, Japan was apparently happy to be the only outside state to contribute to the costs of maintaining services, but as these increased, along with increased use of the straits by other Northeast Asian countries, Japan has sought to involve other countries in cost contributions. In doing so, it has wanted to maintain its preeminent position as the lender of first resort.

United States

The United States is concerned about its strategic mobility between the Indian and Pacific oceans. Most United States navy ships and submarines that operate in the Middle East and the Indian ocean are deployed from bases in Japan, Hawaii, or the west coast of the continental United States. The United States promotes international cooperation in Southeast Asia against the threats of piracy and maritime terrorism. It has provided technical assistance, including a coastal radar system, to Indonesia to help security in the Malacca strait, and the establishment of a training center for marine police. All this puts the United States in a supportive role in regional maritime security rather than in an operational one. As well as U.S.-American assistance with capacity building, the U.S. Pacific Fleet conducts a series of ongoing exercises with countries in the region, including CARAT (Cooperation Afloat Readiness and Training), and annual naval exercises called SEACAT (Southeast Asian Cooperation for Anti-Terrorism). ${ }^{10}$

India

India is actively pursuing its Look East policies and naval cooperation with Southeast Asian countries and, by virtue of the geographic location of the Andaman and Nicobar islands, has claims to being a littoral country to the straits in its own right. Its navy has been showing a growing desire to be involved in safeguarding the Malacca strait. ${ }^{11}$ For example, at the 2006 Shangri-la Dialogue, India's defense minister offered help in any capacity to provide security in the Malacca strait. The navy has been involved in coordinated naval patrols with Indonesia since 2001 and with Thailand since 2005. It is also negotiating similar arrangements with Myanmar and Malaysia. 


\section{Shipowners}

Major shipowning countries in Europe, including France, Germany, Greece, and Norway, are concerned about risks to their ships and crews, as well as the possibility of higher insurance premiums for ships using the straits. Shipowners are wary about the possibility of having to meet the costs of providing services in the straits for safety, security, and environmental protection. This wariness may increase in the future as the economic downturn leads to decreased demand for international shipping services, smaller cargoes, and increased unit-costs.

\section{Regime building}

In the maritime domain, invariably compromise needs to be made between and among the interests of different countries. No country has full independence of action in its offshore zones. Even in its territorial sea, a coastal state must concede the right of innocent passage to ships of other countries, as well as freedom of transit passage and overflight in those areas of its territorial sea that are part of an international strait. Countries must take into account the interests and rights of other states which lawfully send ships into and through waters under national sovereignty. The principles and norms of cooperation need to be institutionalized in the form of a regime for dealing with a common interest, in this case, safety, security, and pollution prevention in the Malacca and Singapore straits. ${ }^{12}$ Countries will only participate in a regime if they believe that the benefits of participation outweigh the costs, including for example, the cost that collective action might involve some loss of sovereignty and freedom of action.

Maritime regimes are based on the framework provided by the 1982 United Nations Convention on the Law of the Sea (UNCLOS). Part III of the Convention deals with straits used for international navigation. The responsibilities of littoral states for providing services to shipping in an international strait are implicitly acknowledged in UNCLOS, Article 43, the so-called burden sharing article. This provides for cooperation between user states and states bordering a strait on the provision of navigational and safety aids and the prevention of marine pollution and is the main basis for a regime for safety, security, and environmental protection in the straits.

UNCLOS, in Article 43, envisages that users should contribute to the costs of safety and environmental protection but leaves the problem of devising a costrecovery mechanism open. Fundamental differences of view on what is meant by burden sharing exist. Littoral states have typically seen this as a matter of sharing the financial costs. But the United States in particular has seen this as a matter of getting more directly involved in providing safety and security possibly through contributions in-kind, such as assistance with patrols and surveillance. Other fundamental questions include whether cost contributions should come from the governments of user states, from flag states, or directly from shipowners, and whether it might it be possible to charge ships a fee for using a strait. These issues have been discussed over the years in many international and regional fora, but a possible formula for burden sharing has only recently evolved.

Economic thinking provides some structure in thinking about regime building and burden sharing.

The economic theory of club goods, built on the contrast between public goods and private goods, is particularly relevant. As the provision of safe passage through the straits is an UNCLOS-mandated public good, shipowners and user states freeload on the safety and security services littoral states provide. (Any measures introduced by bordering states cannot "have the practical effect of denying, hampering or impairing the right of transit passage."13) Because users cannot feasibly be excluded from benefitting from these services - once they are provided — there is no user-incentive to share in the cost of provision. Littoral states themselves can be expected to carry the cost of these services only inasmuch and to the extent that they benefit their own shipping needs. This contrast in perspective explains the widely observed undersupply of safety and security services in international waterways. A viable alternative must be found.

A club good, as the name suggests, shares a good or service among club members, yet effectively excludes nonpayers from benefitting from the provision of the good. How the cost of provision is apportioned among club members (e.g., in equal or in proportional amounts, by means of a fee-per-usage, or by another mechanism) remains for club members to decide. The next two sections detail progress made, and difficulties encountered, by user and littoral states in moving from public good to club good in the straits.

Steps forward

Cooperative mechanism

The Cooperative Mechanism for the Straits of Malacca and Singapore established in September 2007 is the most significant step forward in regime building for the straits. Reflecting their joint responsibility for protecting the environment and promoting navigational safety, this was a major breakthrough in reconciling diverse stakeholder interests. Emerging from a series of meetings sponsored by the IMO in Jakarta in 2005, Kuala Lumpur in 2006, and Singapore in 2007, the Mechanism encourages user 
states and other stakeholders to voluntarily cooperate with Indonesia, Malaysia, and Singapore to enhance safety, security, and environmental protection in the straits. ${ }^{14}$

The Mechanism comprises three elements: a Cooperation Forum, an Aids to Navigation Fund, and specific projects to be managed by a Project Coordination Committee. ${ }^{15}$ The Forum joins littoral states, user states, and other stakeholders. The Fund is intended to enable user states and others to make voluntary contributions to enhance navigational safety and environmental protection by maintaining and replacing aids to navigation such as lighthouses and buoys. Six specific projects have been identified by the littoral countries, including the removal of wrecks in the Traffic Separation Scheme, and cooperation and capacity-building on hazardous and noxious substance preparedness and response. Several countries, including Australia, China, and the United States, have offered to fund or contribute to the funding of these projects.

While the Mechanism is a major step forward, it has some way to go before it is fully effective. Differences have arisen between prospective donor countries and the littoral states over project funding, and shipowners have been reluctant to contribute to the Aids to Navigation Fund. ${ }^{16}$ The 2009 budget for the fund is US\$8 million but current contributions add up to US\$5.4 million only, with US\$2.5 million coming from the Nippon Foundation of Japan; Greece, and a Middle East navigation service contributing one million dollars each; and Korea, the United Arab Emirates, and the Japanese Shipowners' Association contributing lesser amounts. Other shipowner associations have not contributed. Some shipowners appear to subscribe to the notion that passage through a strait used for international navigation should be free under the UNCLOS regime of transit passage, and that a contribution to the fund amounts to a fee for transit that would have to be passed on to shippers, which of course violates the club good notion of cost-sharing (or, alternatively, emphasizes that finding an effective benefit-exclusion mechanism is difficult).

\section{Littoral state cooperation}

The commitment by littoral states to maritime security cooperation constitutes another major step forward with regime building in the Malacca and Singapore straits. Relevant activities include trilateral coordinated maritime surface patrols among Indonesia, Malaysia, and Singapore called the Malacca Strait Sea Patrols (MSSP), and coordinated airborne surveillance under the Eyes in the Sky arrangement. Thailand agreed in late 2008 to participate in the MSSP. Despite these developments, cooperation between and among littoral countries is still rather less than ideal: the coordinated air surveillance is infrequent; the surface patrols are coordinated rather than joint; and there are restrictions on the hot pursuit of suspicious vessels into the territorial sea of another country. ${ }^{17}$

Despite limitations, the situation may improve with further development of ASEAN as a regional institution. For example, the latest summit meeting in February
2009 agreed to the goal of ASEAN becoming a regional economic community by 2015. ${ }^{18}$ ASEAN is establishing a Maritime Forum and ARF has set up an intersessional meeting on maritime security. Both will address maritime cooperation, including shipping safety and security.

$\operatorname{Re} C A A P$

ReCAAP — the Regional Cooperation Agreement on Combating Piracy and Armed Robbery against Ships - is another positive development. The agreement became operational in September 2006 with the opening of the Information Sharing Center in Singapore. ${ }^{19}$ This Japanese-inspired initiative is a very significant achievement that provides the basis for regional cooperation to counter piracy and seaborne robbery in the Asian region. With the important exceptions of Indonesia and Malaysia, it involves all ASEAN nations, plus Japan, China, South Korea, India, Bangladesh, and Sri Lanka. It includes an information network and a cooperation regime with assigned contact points in each participating country.

Indonesia's reluctance to join stems from the belief that ReCAAP undermines state sovereignty in archipelagic waters and the territorial sea. Similar concerns are believed to lie behind Indonesia's reluctance to ratify the 1988 Convention for the Suppression of Unlawful Acts against the Safety of Maritime Navigation (SUA Convention) which, as amended by its 2005 Protocol, potentially provides an international regime for action against piracy and seaborne robbery that overcomes the limitations of the antipiracy regime in UNCLOS. ${ }^{20}$ Malaysia's reluctance to support ReCAAP is believed to lie in its objections to the location of the Information Sharing Center in Singapore and its view that ReCAAP is an unnecessary competitor for the IMB's Piracy Reporting Center located in Kuala Lumpur.

National arrangements

At a national level, tighter government control and onshore policing are important factors contributing to the improved situation with piracy and robbery at sea. As piracy events in 2008 and 2009 off the coast of Somalia demonstrate, corrupt governance or lack of good order onshore facilitates disorder at sea. ${ }^{21}$ Pirates operate from bases onshore, usually in small fishing communities, and it is not unreasonable to assume that most of the community know what is going on. This will include local police or naval personnel who may even be complicit in the illegal activity. Low salaries for law enforcement personnel encourage such complicity.

Official and community attitudes against piracy in Indonesia have hardened in recent years. Indonesian public awareness of acts of piracy committed in Indonesian waters may have been low in the past. Greater awareness and more active policing onshore constitute the most significant factors leading to the reduced incidence of piracy and seaborne robbery in Indonesia, including in the Malacca strait. ${ }^{22}$ 


\section{Step back}

The step back from an effective regime in the Malacca and Singapore straits has several sources, stemming from difficulties in reconciling the interests of different stakeholders, or problems encountered with implementing new arrangements such as the Cooperative Mechanism, or when Indonesia and Malaysia resist initiatives for fear that these might compromise state sovereignty.

Invariably, sovereignty concerns scuttle attempts at regime building by extraregional powers. This was evident, for example, in the reaction to the Regional Maritime Security Initiative, a capacity-building initiative put forward by the United States in $2004 .{ }^{23}$ In fact, sovereignty in the straits should only be an issue in the southern one-third of the Malacca strait where the strait narrows and the territorial seas of the Indonesia and Malaysia overlap. Littoral states only have sovereign rights and not sovereignty in their exclusive economic zones (EEZs) that constitute the other two-thirds of the strait. ${ }^{24}$ Many of the high-seas provisions of UNCLOS, including the antipiracy regime in Articles 100 to 107, apply in this area.

Sovereignty concerns are compounded by the lack of a full suite of maritime boundaries in the straits. Maritime enforcement in the northern Malacca strait, particularly against illegal fishing, is complicated by the lack of an EEZ boundary between Indonesia and Malaysia in that part of the strait. ${ }^{25}$ The agreed continental shelf boundary in this area is to the west, that is, closer to Sumatra, than the median line. Indonesia believes that the EEZ boundary should be the median line, whereas Malaysia claims that it should be coincident with the continental shelf boundary. Maritime boundaries have also not been fully agreed in the eastern and western approaches to the Singapore strait where the three countries need to reach agreement on trilateral turning points.

\section{Conclusion}

Regime building in the Malacca and Singapore straits requires reconciling diverse and divergent interests of disparate stakeholders and acknowledging the concerns of Indonesia and Malaysia about proposals that appear to jeopardize sovereignty. With these problems to overcome, an appropriate diplomatic and technical structure was required to facilitate identification of acceptable cooperative measures and reach agreement upon them. Over the years, the IMO has provided this structure. It has played a key role in fostering cooperation between littoral and other user states as well as by linking in key nongovernmental organizations.

The IMO-sponsored meeting process that began in Jakarta in 2005 demonstrates the utility of transnational institutions in regime building. This has been supported by regional cooperation, including trilateral operational arrangements that, taken together, are an important contribution to peace and stability in the region. There is still some way to go but a good start has been made with building an effective regime for the Malacca and Singapore straits.

Notes

Sam Bateman is a Senior Fellow, Maritime Security Programme, S. Rajaratnam School of International Studies (RSIS), Nanyang Technological University, Singapore. He may be reached at issambateman@ntu.edu.sg.

1. Okanishi (2007). Evidently, in the short-run this prediction will be affected by the current global economic recession and the consequent downturn in international shipping services. By 2020, trend growth may have been recovered so that the prediction may well turn out to be correct.

2. Luft and Korin (2004).

3. IMB (2009, Table 1, p. 5).

4. This was evident in the reaction by Indonesia and Malaysia to the United States' Regional Maritime Security Initiative (RMSI). See Young (2007, p. 84).

5. Bateman, Ho, and Raymond (2006, p. 16).

6. For example, a conference in Malaysia in 2004 on Building a Comprehensive Security Environment in the Straits of Malacca organized by the Maritime Institute of Malaysia included a session on Perspectives from Littoral and User States, but there was no perspective included from Singapore. See Basiron and Dastan (2006).

7. An APEC study concluded that a five week closure of the Malacca strait would cost APEC economies US $\$ 1.7$ billion (in 2002 dollars) in terms of oil supply disruption. See Hogan, et al. (2005, p. 152).

8. Nippon Foundation (2006); Anis (2008).

9. Lanterne (2008).

10. Bradford (2008, p. 485).

11. Andaman and Nicobar islands: Sawhney (2006). Navy: Arsyad. (2008, p. 177).

12. Writers define "regime" in different ways, but most are agreed that a regime refers to norms, rules, and procedures that regulate particular areas of public policy. See, e.g., Haas (1980, p. 358). 


\section{UNCLOS, Article 42(2).}

14. Breakthrough: Djalal (2008, p. 3). Meetings: Sasakawa (2007).

15. Terashima (2009).

16. Jegasthesan and Sam (2008).

17. Commitment: Bradford (2008, p. 474). Thailand: Storey (2009). The Eyes in the Sky program is a coordinated airborne surveillance program.

\section{Fuller (2009).}

\section{Singapore Government (2006).}

20. Indonesian reluctance: Bradford (2008, p. 489). SUA Convention: Beckman (2008, pp. 188-192).

\section{Bateman and Ho (2008).}

22. Low awareness: vom Busch and Rettig (2006, p. 88). Greater awareness: Bradford (2008, p. 480).

23. Sovereignty concerns: Huang (2008, p. 96). Regional Maritime Security Initiative: Storey (2008, p. 113).

24. There is a clear distinction between the exercise of sovereignty within internal waters, archipelagic waters and the territorial sea, and the exercise of sovereign rights in the EEZ and on the continental shelf. "Sovereign rights" pertain to a functional jurisdiction (notably over resources and environmental protection) that is more limited in character than "sovereignty."

25. Bateman, Ho, and Chan (2009, p. 16).

\section{References}

Anis, M.N. 2008. "RM14m Boost for Straits of Malacca Security." The Star Online [Kuala Lumpur]. 25 January 2008. http://thestar.com.my/news/story.asp?file= /2008/1/25/nation/20080125182232\&sec=nation [accessed 27 January 2008].

Arsyad. R. 2008. "Cooperation to Safeguard Shipping through the Malacca Strait," pp. 175-186 in A. Forbes, ed. Papers in Australian Maritime Affairs, No. 23. Canberra: Sea Power Centre Australia.
Basiron, M.N. and A. Dastan. 2006. "Building a Comprehensive Security Environment in the Straits of Malacca." Kuala Lumpur: Maritime Institute of Malaysia.

Bateman, S., J. Ho, and C. Raymond. 2006. "Safety and Security in the Malacca and Singapore Straits: An Agenda for Action." Singapore: Institute of Defence and Strategic Studies (IDSS).

Bateman, S. and J. Ho. 2008. "Somalia-type Piracy: Why it will not happen in Southeast Asia.” RSIS Commentary 123/2008. Singapore: S. Rajaratnam School of International Studies.

Bateman, S., J. Ho, and J. Chan. 2009. "Good Order at Sea in Southeast Asia." Singapore: S. Rajaratnam School of International Studies (RSIS).

Beckman, R.C. 2008. "The 1988 SUA Convention and 2005 SUA Protocol: Tools to Combat Piracy, Armed Robbery and Maritime Terrorism," pp. 187-200 in R Herbert-Burns, S. Bateman, and P. Lehr, eds. Lloyd's MIU Handbook of Maritime Security. Boca Raton, FL: CRC Press.

Bradford, J.F. 2008. "Shifting the Tides against Piracy in Southeast Asian Waters." Asian Survey. Vol. 48, Issue 3, pp. 473-491.

Djalal, H. 2008. "The Development of Cooperation on the Straits of Malacca and Singapore." Paper presented to International Symposium on Safety and Protection of the Marine Environment in the Malacca and Singapore Straits. Kuala Lumpur, 24 November. www.nippon-foundation.or.jp/eng/current/malacca_sympo/6.doc).

Fuller, T. 2009. “At Asean, Reaching Out to Regular People.” International Herald Tribune. 1 March 2009. http://www.iht.com/articles/2009/03/01/asia/asean.php [accessed 4 March 2009].

Haas, E.B. 1980. "Why Collaborate? Issue-linkage and International Regimes.” World Politics. Vol. 32, No. 3.

Hogan, L., L. Fairhead, A. Gurney, and R. Pritchard, R. 2005. "Energy Security in APEC: Assessing the Costs of Energy Supply Disruptions and the Impacts of Alternative Energy Security Strategies.” APEC Energy Working Group, Report No. APEC\#205-RE-01.5. Published by the Australian Bureau of Agricultural and Resource Economics (ABARE) as Research Report 05.2, Canberra, June.

Huang, V. 2008. "Building Maritime Security in Southeast Asia: Outsiders Not Welcome?" Naval War College Review. Vol. 61, No. 1, pp. 87-105.

[IMB] International Maritime Bureau. 2009. "Piracy and Armed Robbery Against Ships. Annual Report for the Period 1 January- 31 December 2008."

Jegasthesan, M. and I. Sam. 2008. "Ship Owners Urged to Help Keep the Malacca Straits Safe." Channel News Asia [Singapore]. 24 November 2008 http://www.channelnewsasia.com/stories/afp_asiapacific/view/391875/1/.html [accessed 26 November 2008].

Lanterne, M. 2008. "China's Maritime Security and the 'Malacca Dilemma'." Asian Security. Vol.4, No. 2, pp. 143-161.

Luft, G. and A. Korin. 2004. "Terrorism Goes to Sea.” Foreign Affairs. Vol. 83, No. 
6, pp. 61-71.

Nippon Foundation. 2006. "The Nippon Foundation Donates Training Ship to Malays.” 1 June 2006. http://www.nippon-foundation.or.jp/eng/news/2006/ brief_dtl/2006753/20067532.html [accessed 10 April 2009].

Okanishi, Y. 2007. "Emerging Trends in Vessel Traffic through the Straits." Presentation to Singapore Meeting on the Straits of Malacca and Singapore: Enhancing Safety, Security and Environmental Protection, 4-6 September 2007. Ministry of Land, Infrastructure and Transport, Japan. IMO document IMO/SGP1/INF.21. 5 September 2007.

Sasakawa, Y. 2007. "Towards a New World Maritime Community: Cooperative Framework for the Future of the Malacca and Singapore Straits." RSIS Commentary 17/2007. Singapore: S. Rajaratnam School of International Studies. Sawhney, R. 2006. "Redefining the Limits of the Straits: A Composite Malacca Straits Security System.” RSIS Commentary 37/2006. Singapore: S. Rajaratnam School of International Studies.

Singapore Government. 2006. "Fact Sheet on Regional Cooperation Agreement on Combating Piracy and Armed Robbery against Ships in Asia (ReCAAP)." http://app.mot.gov.sg/data/ReCAAP\%20factsheet \%20 Nov06 \%20\%5BFINA L\%5Das\%20of\%20281106.pdf [accessed 21 January 2007].

Storey, I. 2008. "Securing Southeast Asia's Sea Lanes.” Asia Policy. No. 6, pp. 95 128.

Storey, I. 2009. "Calming the Waters in Southeast Asia." Asia Pacific Bulletin. No. 29 (available at www.EastWestCenter.org/apb).

Terashima, H. 2009. “Transit Passage and Users' Contributions to the Safety of the Straits of Malacca and Singapore," pp. 357-368 in M.H. Nordquist, T.B. Koh, and J.N. Moore, eds. Freedom of Seas, Passage Rights and the 1982 Law of the Sea Convention. Leiden: Martinus Nijhoff.

vom Busch, W. and T. Rettig, eds. 2006. Maritime Piracy in Southeast Asia. Singapore: Konrad Adenauer Stiftung.

Young, A.J. 2007. "Maritime Piracy in Southeast Asia." Singapore: Institute of Southeast Asian Studies (ISEAS). 